\title{
FIRST NEOTROPICAL MUTUALISTIC ASSOCIATIONS IN BUMBLEBEE NESTS (HYMENOPTERA: APIDAE)
}

\author{
By Gabriela ChaVARria \\ Museum of Comparative Zoology \\ Harvard University \\ Cambridge, MA 02138
}

\begin{abstract}
Ectosymbionts of bumblebee nests of Bombus ephippiatus are recorded for first time from the American Tropics. An overview of this interaction is provided.

"The insect colony and its immediate environment can be thought of as an island which symbiotic organisms are continuously attempting to colonize"

E.O. Wilson, 1971

\section{INTRODUCTION}

Much is known about the enemies and inquilines which, directly or indirectly, affect the existence of the bumblebees (Alford, 1975). Many occur in nests as either accidental visitors or harmless scavengers, some may be beneficial, but several are either parasites of adult bees or they damage the brood or the comb. A large number act either as social parasites as in the case of Psithyrus Lepeletier (Hymenoptera: Apidae) (Sladen, 1915; Frison, 1916, 1921; Plath, 1922a), or as parasites of the adults, larvae and pupae as in the case of the conopid flies Physocephala sagittaria (Say) (Packard, 1865; Meijere, 1904; Frison, 1918), Spherularia bombi Dufour (Réaumur, 1742; Leuckart, 1887), Brachycoma sarcophagina (Townsend)(Davidson, 1894; Sladen, 1912; Plath, 1922b), Mellitobia sp. (Frison, 1926), Parasitus sp. (Oudemans, 1902; Banks, 1919; Richards, 1976; Richards and Richards, 1976), or as insect enemies of the bumblebee comb, like the pyralid moths Vitula edmandsii (Packard) (Franklin, 1912-13; Frison, 1918) and Plodia
\end{abstract}

Manuscript received 17 April 1994. 
interpunctella Hübner (Davidson, 1894), or as scatophagus associates and occasional lodgers. A number of insects act as scavengers within the bumblebee nest. Among the most interesting of these is the beetle Antherophagus Latreille (Coleoptera: Cryptophagidae). Many European and American investigators record the capture of Antherophagus (pallens F., silaceus Herbst and nigricornis F.) in the nests of bumblebees. As Carus and Gerstaecker (1863) stated of Antherophagus: "The species live on flowers, attach themselves to bumble-bees and permit the latter to transport them to their nests, probably for the purpose of oviposition." In fact several authors (Gorham, 1869; Perris, 1869-70; Bugnion, 1869-70; Seidlitz, 1869-70) described seeing the larvae of these beetles in the nests of bumblebees.

Several observations have been made comparing the European and American beetle species and have found that both species are similar in habits. The adults of Antherophagus gain admittance to the nests of bumblebees often if not always by attaching themselves to the proboscis of bumblebees while the bees are feeding at the flowers. They are then carried back to the nests and upon releasing their hold fall onto the comb and eventually reproduce in the debris of the nest, particularly at the bottom of the comb. Packard (1864) said that these beetles have a certain attraction for sweet flowers and that they visit the nests of the bees for the purpose of consuming the honey stored there, but Packard (1873) inferred that the beetles probably feed upon the wax and pollen. However, it seems that the views of various other authors are unanimous concerning the feeding habits of the larva. Perris (1875) says that the larvae of Antherophagus probably play the same role in the bumblebee nests as do Cryptophagus in the nests of wasps, "they live on the feces of the inhabitants and that they are, properly speaking, merely scavengers" and that seems to be the most realistic explanation.

\section{Material AND Methods}

During a field trip to Cerro de la Muerte, Costa Rica in July, 1993 and January, 1994, while collecting bumblebee nests for studies on nesting behavior, the author collected four nests of Bombus ephippiatus Say. The bumblebee nests were collected at Cerro de la Muerte in the Talamanca Cordillera in Costa Rica. Some other 
nests of other bumblebee species were collected in other areas and contained no ectosymbionts. Several bees were collected while flying and while foraging; observations were made also on several flower patches, in order to find a possible phoretic organism.

Bumblebee nests were dissected and all inquilines were placed in $80 \%$ ethanol and samples of the different inquilines were sent to Q.D. Wheeler and P. Fraissinet (Cornell University) for identification. Field collected adult bumblebees were pinned.

\section{RESULTS AND DisCUSSION}

Adults, larvae, and pupae of a number of species of different families of primarily Coleoptera and Diptera were found in all four nests (Table 1), and a new species of Antherophagus (Wheeler and Fraissinet, pers. comm.) is reported for the first time. The study of bumblebee nests is at an early stage, therefore, not so many nests of Neotropical bumblebees have been studied in detail. Flies (Phoridae) were also found; this is not unusual because phorid flies have been reported as guests of many social insects, including bumblebees (Wilson, 1971).

Of the bumblebees that were collected while flying or foraging (157 specimens), none had any inquilines except for mites.

All bumblebee colonies were very active and were producing a lot of brood, and in two cases the colonies were producing queens. This activity in the nests, in conjunction with the presence of several inquilines, demonstrates that the inquilines are probably obligate ectosymbionts (Wilson, 1971) in some kind of relationship other than internal parasitism.

In 1982 Roubik and Wheeler mentioned Roubik's personal observation of a nest of $B$. atratus Franklin, kept in captivity at the Universidad Nacional de Colombia in Bogotá, where beetles of the genus Antherophagus lived in the nest and left phoretically on foraging bees; however aside from this report, such behavior has not been mentioned for the Neotropical bumblebees.

More studies are needed, especially field work, in order to understand truly the behavior and other patterns of these beetles, including whether there is any specificity in relation to different bumblebee species. This type of study will contribute to a better understanding of the host relationships. Finally, the concept of an insect colony as a partially isolated ecosystem can be extended and 


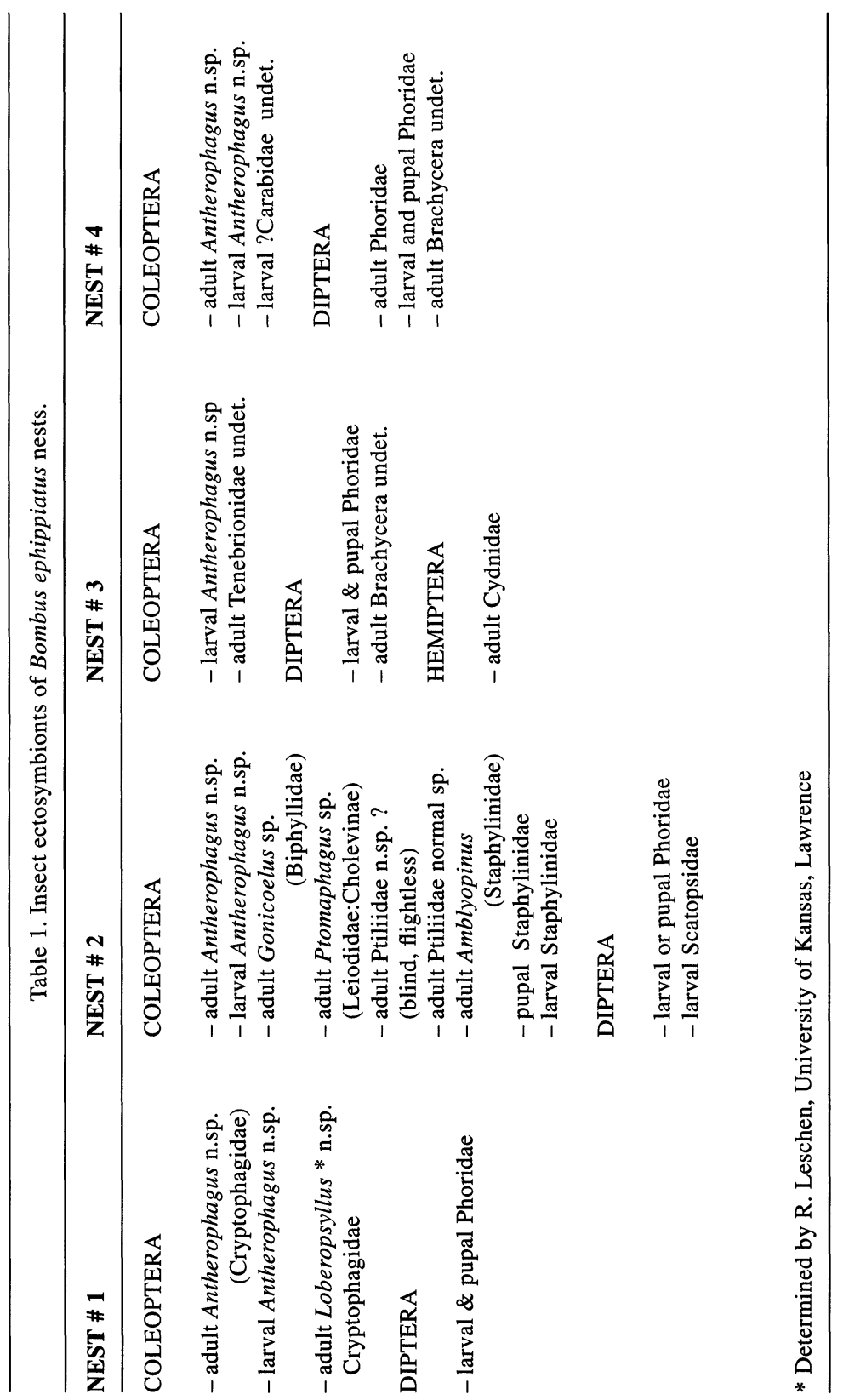


this way we can gain a better understanding of biological aspects of the symbionts.

\section{ACKNOWLEDGEMENTS}

I would like to thank Quentin D. Wheeler and Peter Fraissinet (Cornell University) for identifying the material in the nests. I thank Adam Lazarus for assistance in the field. I would like to express my gratitude to the people at la Georgina and Villa Mills, Cerro de la Muerte Costa Rica for their hospitality and help in finding the nests. The field work in Costa Rica was supported by a post-course award from the Organization for Tropical Studies (OTS) and the Pew Charitable Trust, and the Graduate Student Council, Harvard University.

\section{LITERATURE CITED}

Alford, D. V. 1975. Bumblebees. Davis-Poynter, London. 352 pp.

Banks, N. 1919. The Acarina collected by the Canadian Arctic Expedition 1913-1918. Rep. Canadian Arctic Exped. 3. Part H. pp. 11-13.

Bugnion, E. 1869-70. Letter to Perris on Antherophagus. L'Abeille 7:26-27.

Carus, J. V., and A. Gerstaecker. 1863. Handbuch der Zoologie. Leipzig, W. Engelmann. Vol. 2.

Davidson, A. 1894. On the parasites of wild bees in California. Ent. News 5:170-172.

Franklin, H. J. 1912-13. The Bombidae of the New World. Trans. Amer. Ent. Soc. 38(3-4): 177-486, 39(2):73-200.

Frison, T. H. 1916. Note on the habits of Psithyrus variabilis Cress. Bull. Brooklyn Ent. Soc. 2:46-47.

1918. Additional notes on the life history of Bombus auricomus Robt. Ann. Ent. Soc. Amer. 11:43-48

- 1921. Psithyrus laboriosus Fabr. in the nests of Bumble bees. Can. Ent. 53: $100-101$.

- 1926. Contribution to the knowledge of the inter-relations of the bumblebees of Illinois with their animate environment. Ann. Ent. Soc. Amer. 19: 203-235.

Gorham, H. S. 1869. Leptinus in bees' nests. Ent. Month. Mag. 6:89.

Leuckart, R. 1887. Neue Beiträge zur Kenntnis des Baus und der Lebensgeschichte der Nematoden. Abh. sächs. Akad. Wiss. 22:565-704.

Meijere, J. C. H. de. 1904. Beiträge zur Kenntnis der Biologie und der systematischen Verwandtschaft der Conopiden. Tijdschr. Ent. 46:144-224.

Oudemans, A. C. 1902. New list of Dutch Acari. Second part, with remarks on known and descriptions of a new family, genera and species. Tijdschr. Ent. 65: $1-52$.

Packard, A. S. 1864. The humble-bees of New England and their parasites, with notes of a new species of Antherophorabia and a new genus of Proctrupidae. Proc. Essex Inst., 4:107-140. 
1865. The humblebees of New England and their parasites. Proc. Essex Inst. 4:107-140, $1 \mathrm{pl}$.

1873. Our common insects. Salem, Naturalists' Agency. 1-225 pp.

Perris, E. 1869-70. Note on Antherophagus nigricornis. L'Abeille 7:9-10, 25-27. 1875. Larves des Coléoptères. Ann. Soc. Linn. Lyon 22:259-418.

Plath, O. E. 1922a. Notes on Psithyrus, with records on two American hosts. Biol. Bull. 43:23-44.

1922b. Notes on the nesting habits of several North American Bumblebees. Psyche 29:189-202.

Réaumur, R. A. F. 1742. Mémoires pour servir à 1'histoire des insectes. L'imprimerie Royale, Paris, 6:1-38.

Richards, L. A. 1976. Parasitid mites associated with bumblebees in Alberta, Canada (Acarina: Parasitidae; Hymenoptera: Apidae). I. Taxonomy. Univ. Kansas Sci. Bull. 50(13):731-773.

Richards, L. A., and Richards, K. W. 1976. Parasitid mites associated with bumblebees in Alberta, Canada (Acarina: Parasitidae; Hymenoptera: Apidae). II. Biology. Univ. Kansas Sci. Bull. 51(1):1-18.

Roubik, D. W., and Wheeler, Q. D. 1982. Flightless beetles and stingless bees: phoresy of scotocryptine beetles (Leiodidae) on their meliponine hosts (Apidae). J. Kansas Ent. Soc. 55:125-135.

Seidlitz, G. 1869-70. Note on Antherophagus nigricornis. L'Abeille 7:62-63.

Sladen, F. W. L. 1912. The humble-bee, its life history and how to domesticate it. Macmillan \& Co. London. 283 pp. 1915. Inquiline Bumble-Bees in British Columbia. Can. Ent. 47:84.

Wilson, E. O. 1971. Insect Societies. Harvard University Press. 548 pp. 

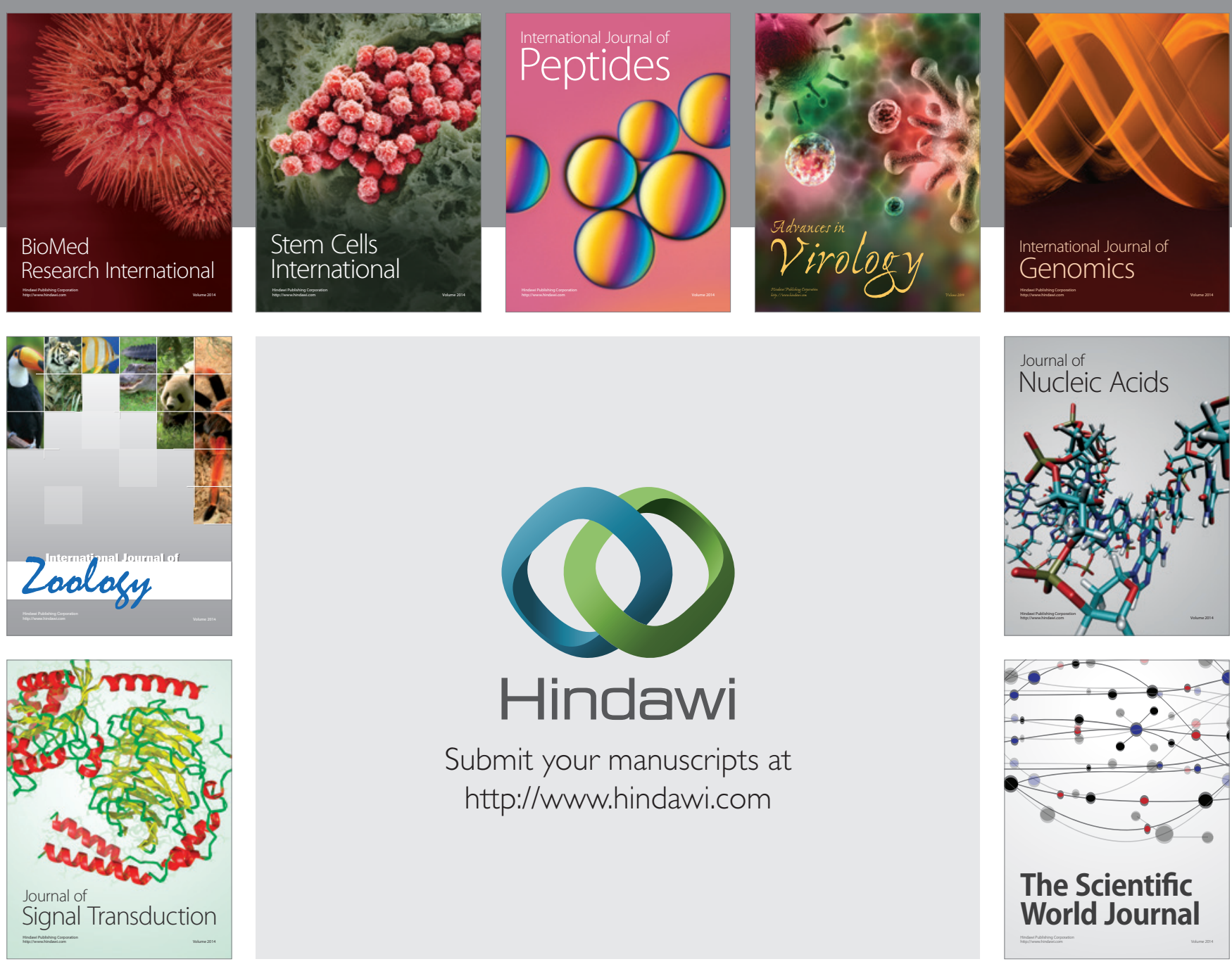

Submit your manuscripts at

http://www.hindawi.com
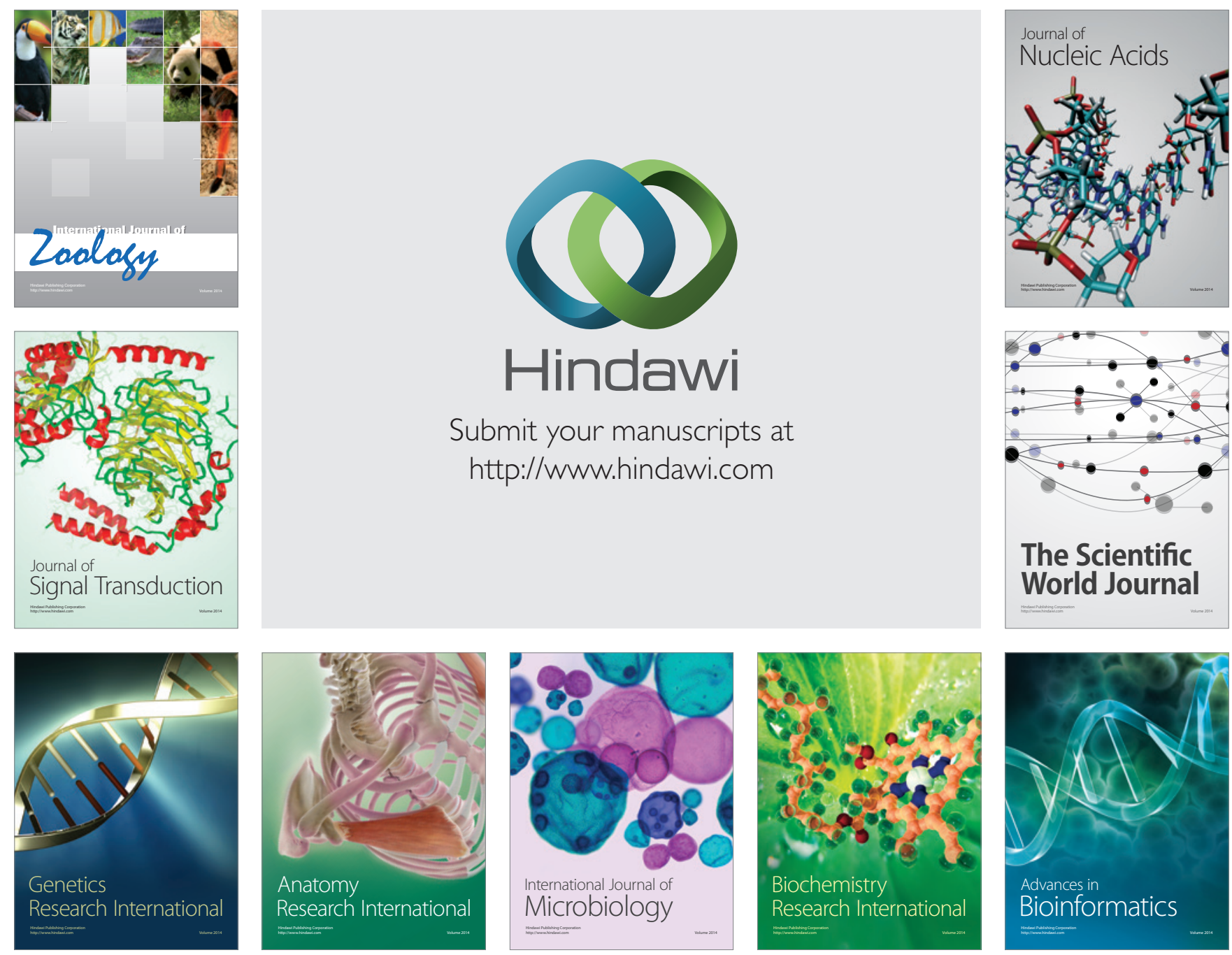

The Scientific World Journal
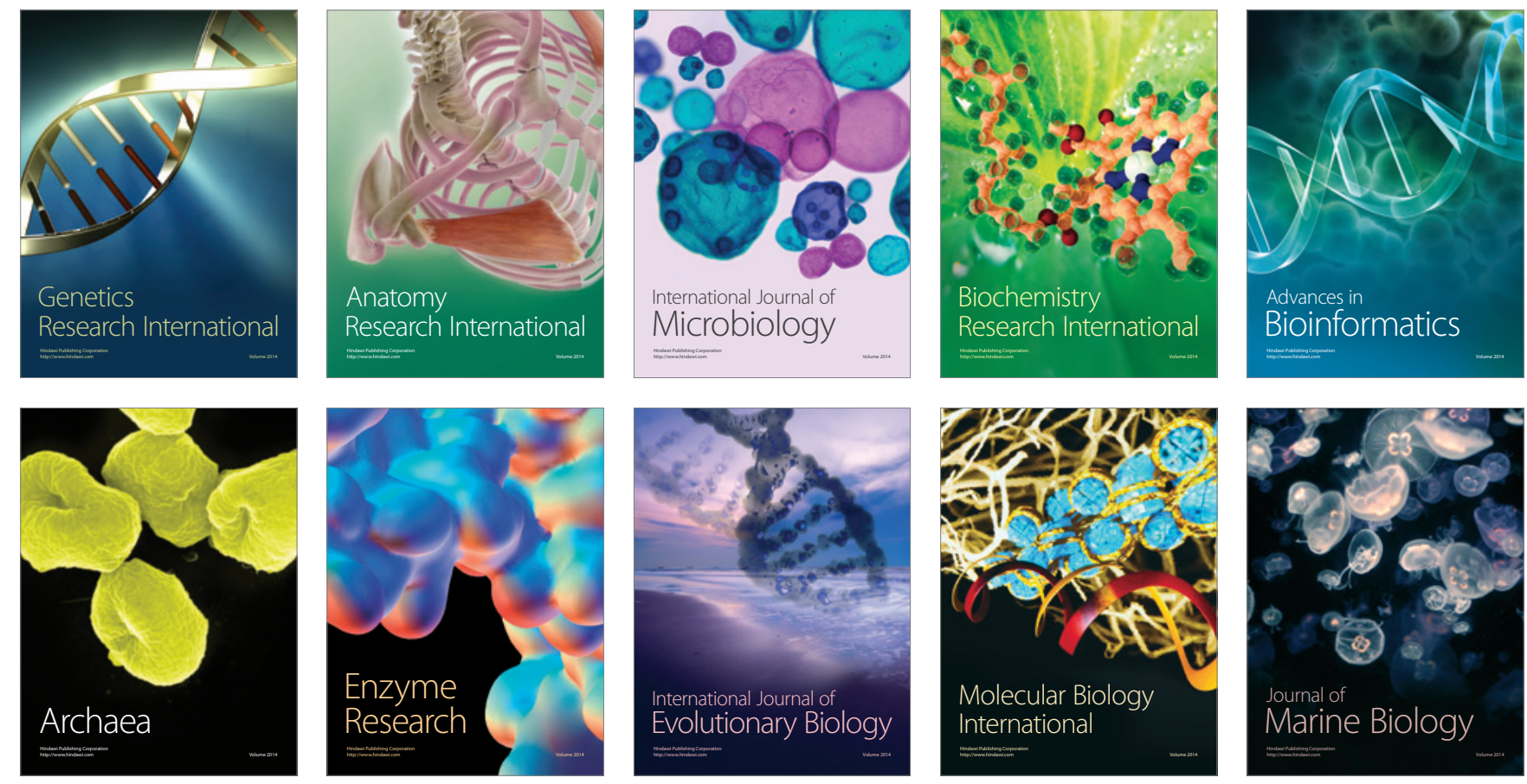